\title{
A vontade geral e o sistema autogestionário: necessidade, possibilidade e desafios
}

\author{
The general will and the self-managing system: need, possibility \\ and challenges
}

\section{Luiz Carlos Mariano da Rosa'}

Resumo: Consistindo em um processo ético-jurídico de deliberação coletiva, o que se impõe à manifestação da Vontade Geral como um fenômeno histórico-cultural é a condição de imanência que a caracteriza em um movimento dinâmico-dialético que demanda uma formação econômico-social que possibilite a emergência de valores e práticas, condutas e comportamentos, necessidades e objetivos que, tendo como fundamento o interesse comum, se lhe correspondam, convergindo para uma forma de autodeterminação que guarda possibilidade de promover a superação da alienação das capacidades humanas no contexto das relações socioprodutivas, a saber, a autogestão. Tal experiência social de autodeterminação coletiva, conforme assinala o artigo, envolve tanto a esfera política quanto o âmbito econômico (trabalho) e encerra a noção que implica desde a igualdade substancial (concreta) até a efetiva participação política, sobrepondo-se ao viés mercadológico da organização econômico-social vigente e à estrutura burocrática corporificada pelo Estado no sistema capitalista.

Palavras-chave: Vontade Geral; autogestão; econômico; político.

Abstract: Consisting in an ethical-legal process of collective deliberation, which is imposed on the manifestation of the General Will as a historicalcultural phenomenon its the immanence condition that characterizes it in a dynamic dialectical movement that demands a social-economic formation that enables emergency of values and practices, conducts and behaviors, needs and goals, based in the common interest, that correspond to these, converging to a form of self-determination that keeps possibility to promote overcoming of alienation of human capabilities in the context of socio-productive relations, namely, self-management. This social experience of collective selfdetermination, as noted in the article, involves both the political sphere and the economic sphere (work) and encloses the notion that implies since the substantial equality (concrete) even the effective political participation, overlapping to the marketing bias of present economic and social organization and the bureaucratic structure embodied by the State in the capitalist system.

Keywords: General Will; self-management; economic; politician.

1 Professor voluntário e pesquisador independente no Espaço Politikón Zôon. 


\section{Aspectos Introdutórios}

Perfazendo o "princípio dinâmico" de uma determinada sociedade, a Vontade Geral se lhe impõe legitimidade racional, à medida que guarda a pressuposição que implica o interesse comum como base da ordem político-social, conforme defende a leitura rousseauniana, que assinala um processo de deliberação coletiva que, não deixando de se lhe atribuir a unanimidade como necessária, se lhe mantém atrelada à generalidade virtual dos cidadãos, aos quais se torna, nesta perspectiva, passível de reconhecimento, haja vista a sua constituição identitária como tais na esfera da totalidade ético-jurídica e econômico-política ora designada como Estado. Dessa forma, pois, o que se impõe ao homem é o caráter coletivista (comunitarista) que, guardando correspondência com a condição característica do membro do soberano, sobrepõe-se, segundo o contrato social, ao status que implica o bomo oeconomicus e converge para as fronteiras que encerram o "individualismo possessivo", tendo em vista a imanência que necessariamente envolve a construção e o exercício da liberdade e a fruição da igualdade, cuja experiência não requer senão a correlação envolvendo a realidade históricocultural e a formação econômico-social, que se thes subjazem e determinam.

Ao mundo do associativismo voluntário da sociedade civil, que encerra a noção que envolve a possibilidade do exercício da autonomia dos indivíduos, tanto quanto da manifestação e usufruto dos seus interesses, o que se impõe é uma indiferenciação que confere equivalência às formas de cooperação, participação e voluntarismo que caracterizam a constituição e o funcionamento das empresas, sobrepondo-se à condição que assume a unidade básica da organização econômica da produção capitalista, cujo tipo de associação escapa às

\footnotetext{
2 A noção que envolve "individualismo possessivo" emerge da teoria de Crawford Brough Macpherson (1911-1987), professor e sociólogo canadense, que, analisando o contratualismo proposto tanto por Hobbes como por Locke, afirma: "A essência humana é ser livre da dependência das vontades alheias, e a liberdade existe como exercício de posse.” (MACPHERSON, 1979, p. 15)
} 


\section{REVISTA OPINIÃO FILOSÓFICA, PORTO ALEGRE, V. 08; №. 01, 2017}

fronteiras em questão, à medida que não se enquadra na acepção que tem como base o voluntarismo, além de se configurar a formatação da sua vontade um processo que se circunscreve a um percentual mínimo daqueles que o perfazem, excluindo da sua elaboração os demais, que integram a maioria dos que em seu âmbito atuam.

Se as vontades individuais se impõem como a origem do poder, constituindo os seus elementos essenciais, não é senão no seu conjunto que este emerge, à medida que demanda, no que tange à comunidade, uma vontade comum, para a qual converge uma unidade que perfaz um todo que encerra, em suma, a possibilidade que implica do querer à ação, encerrando a Vontade Geral uma condição de imanência que, por esse motivo, não pode emergir senão da formação econômico-social, escapando ao caráter de uma construção cuja existência corresponda ao produto de uma relação de exterioridade, se lhe instaurada por uma esfera independente que, em suma, se lhe sobreponha ${ }^{3}$.

Nessa perspectiva, as vontades individuais, por si somente, não guardam capacidade suficiente, no âmbito da comunidade, para a constituição do poder senão no seu conjunto, uma vez que é este que gera a Vontade Geral, que mais do que a soma das vontades particulares se impõe como a força que sobrepõe o comum ao privado, legislando em função do público, o que implica na impossibilidade de uma correlação senão antagônica envolvendo o sistema representativo e a Vontade

3 Nesta perspectiva, alcança relevância a condição atribuída à vontade como vontade de atuar, cujo movimento, guardando correspondência originariamente com "um princípio jurídico", converge para as fronteiras que encerram a "civilização burguesa", tendo em vista a função determinante da formação econômico-social na constituição da realidade histórico-cultural, segundo Gramsci: "As ordens actuais foram suscitadas pela vontade de actuar totalmente um princípio jurídico. Os revolucionários de 1789 não previam a ordem capitalista. Queriam actuar os direitos do homem, queriam que fossem reconhecidos aos componentes da colectividade determinados direitos. Depois do rasgão inicial da velha casca, estes foram-se afirmando, foram-se concretizando e tornados forças operativas a partir de factos, plasmaram-nos, caracterizaram-nos e daí desabrochou a civilização burguesa, a única que podia desabrochar porque a burguesia era a única energia social criadora de facto e realmente operante na história. Os utopistas foram derrotados também nessa altura porque nenhuma das suas particulares previsões se realizou. Mas realizou-se o princípio e deste floriram as ordenações actuais, a ordem actual." (GRAMSCI, 1976, pp. 114-115) 
Geral. Tal condição emerge tendo em vista que, perfazendo a unificação das vontades individuais, a Vontade Geral, expressando o interesse comum, não se impõe senão como a unidade que governa e sistematiza a vida humana no âmbito da organização social e cuja manifestação demanda a exclusão de qualquer tipo de mediação que, além da inviabilidade da sua tradução, subtrai ao cidadão, no que tange à totalidade éticojurídica e econômico-política, o poder de constituição da forma institucional que se lhe tem como conteúdo real e com a qual não pode manter uma relação de exterioridade, sob pena de destituir o Estado da vitalidade que o seu funcionamento requer como a encarnação da universalidade concreta.

Demandando uma igualdade que, sobrepondo-se ao caráter formal, converge para as fronteiras econômicas, e dialogando com o processo que guarda possibilidade de que o produto das riquezas, constituindo um patrimônio que traz como origem uma construção coletiva, seja distribuído de forma que todos se lhe tenham acesso real, se lhe usufruindo, pois, igualitariamente $^{4}$, a saber, o sistema autogestionário $^{5}$, a emergência da Vontade Geral não pressupõe senão uma relação dialética que abrange a base material, que envolve a atividade produtiva, e a esfera ética, que corresponde ao exercício da cidadania plena e ativa participação política ${ }^{6}$. O processo em

4 Cabe registrar, nessa perspectiva, a crítica de Proudhon acerca do referido desequilíbrio econômico-social: "Se o trabalho é a fonte de toda a riqueza, se é o guia mais seguro para seguir-se a história dos estabelecimentos humanos sobre a face do globo, como a igualdade na distribuição, a igualdade na medida do trabalho, não seria uma le??

Se, ao contrário, existem riquezas que não provêem do trabalho, como a posse destas riquezas é um privilégio? Qual é a legitimidade do monopólio? Que se exponha pois, de uma vez por todas, esta teoria do direito ao consumo improdutivo, esta jurisprudência do belprazer, esta religião da ociosidade, prerrogativa sagrada de uma casta de eleitos!" (PROUDHON, 2003, p. 173, grifos meus)

5 Nesta perspectiva, convém salientar a correlação envolvendo liberdade e igualdade que, consistindo na base da autogestão, a leitura proudhoniana estabelece: "A associação livre, a liberdade que se limita a manter a igualdade nos meios de produção e a equivalência nas trocas é a única forma possível de sociedade, a única justa, a única verdadeira.” (PROUDHON, 1975, p. 247)

6 Consistindo na apropriação do patrimônio socialmente construído, tanto quanto na atualização das potencialidades de realização humana disponibilizadas em cada contexto historicamente determinado, o conceito de cidadania guarda raízes nas 
questão implica, como expressão do bem comum, a superação da tendência à ruptura que se manifesta entre o Estado e a sociedade civil no que tange ao poder que, caracterizando-se como o próprio povo enquanto tal, supõe uma soberania cujo exercício se sobrepõe à forma representativa e demanda uma prática direta ${ }^{7}$.

\section{A Vontade Geral e a integração dinâmico-dialética: a necessidade e a possibilidade da correlação envolvendo liberdade e igualdade}

Quando se propõe uma lei na assembleia do povo, o que se lhes pergunta não é precisamente se aprovam ou rejeitam a proposta, mas se estão ou não de acordo com a vontade geral que é a deles; cada um, dando o seu sufrágio, dá com isso a sua opinião, e do cálculo dos votos se conclui a declaração da vontade geral. (ROUSSEAU, 1999, p. 205)

A participação do homem enquanto indivíduo em sua concreticidade histórico-cultural e econômico-social em um processo que se mantém sob a égide do bem comum e pressupõe, no âmbito do corpo coletivo e moral que traz subjacente o antagonismo envolvendo os interesses privados e as vontades particulares, a possibilidade do seu conhecimento como condição para a construção de decisões que se lhe correspondam em virtude da constituição identitária do cidadão enquanto tal, não implica senão uma integração para a qual converge o reconhecimento da forma institucional ora designada como Estado no que concerne à sua autonomia de pensamento e de

fronteiras que encerram a idéia de soberania popular, implicando a emergência efetiva das condições sociais e institucionais capazes de possibilitar ao conjunto dos cidadãos a participação ativa na formação do governo e, consequentemente, no controle da vida social, convergindo o seu caráter "pleno" para um processo que envolve o exercício dos direitos nas esferas civil, política e social, segundo o contributo do sociólogo britânico T. H. Marshall.

7 Tendo em vista a perspectiva que sublinha que "cada um, determinando-se livremente por adesão ao que compreende ser o melhor para si mesmo, encontra todos os outros sujeitos racionais para ajustar livremente a instituição do mesmo contrato que realiza a Vontade Geral. Assim, todos os membros do corpo social se dão a si mesmos (criam contratualmente) uma lei geral (e isso será a autonomia) que os organiza sem gerar entre eles diferenças de poder, num sistema federal cuja 'circunferência está em toda parte, o centro em parte alguma'.” (GUILLERM; BOURDET, 1976, p. 52) 
ação no sentido que encerra a sua relação com o todo que, sob a acepção de uma totalidade ético-jurídica e econômico-política, se lhe sobrepõe mas não o anula, nem se lhe nega a especificação, à medida que o referido processo se lhe atribui, como membro do soberano, o poder que detém a sua superação.

Se o que se impõe à leitura rousseauniana é a possibilidade que envolve a introdução, no âmbito da soberania popular, da racionalidade política, a instituição da "Vontade Geral" se sobrepõe à referida questão, guardando a sua emergência correspondência com o consenso unânime dos indivíduos, consistindo, dessa forma, no único princípio de legitimidade democrática. Por essa razão, a constituição da vontade coletiva dos cidadãos, em relação à pluralidade de vontades individuais e interesses particulares, emerge como um problema de relevância, à medida que se a transposição das vontades individuais à Vontade Geral prescinde de um modo que a viabilize, se lhe escapando à explicitação que demanda a teoria, a suposição quanto à supressão da pluralidade de vontades e interesses, concernente à sua instauração, se interpõe como a única justificativa que, uma vez evocada, reclama a superação para a qual a sua própria natureza tende - e isto sob pena de se tornar, em suma, contraproducente, incorrendo, pois, na negação do sistema que pretende legitimar.

Nessa perspectiva, pois, a Vontade Geral emerge como possibilidade da instituição ora designada como Estado superar a condição que o encerra nas fronteiras de uma abstração ideal ${ }^{8}$, convergindo para a concreticidade de uma realidade históricocultural que sobrepõe, em suma, o conteúdo (aspecto social) à forma (caráter jurídico) em um processo que implica na fusão que

8 Tendo em vista a perspectiva que assinala que "como ideia-limite, o programa liberal cria o Estado ético, isto é, um Estado que idealmente está acima das competições de classe, do cruzamento e choque dos agrupamentos que compõem a realidade económica e tradicional. Este Estado é mais uma aspiração política do que uma realidade política; existe apenas como modelo utópico mas este seu ser é precisamente uma miragem que o torna robusto e o transforma numa força de conservação. $\mathrm{Na}$ esperança que ele se realize finalmente na sua completa perfeição, muitos encontram a força para o não renegarem e, portanto, para não procurarem substituí-lo." (GRAMSCI, 1976, p. 115) 
envolve ser e dever ser no que tange ao vir-a-ser que se impõe à sua construção, à medida que tende à integração de valores e práticas, condutas e comportamentos, necessidades e objetivos, os quais, não guardando senão condição de imanência em face da sua constituição, resultam na concretização da totalidade éticojurídica e perfazem a universalidade que lhe cabe como tal.

Se o Estado não se circunscreve à condição que envolve um todo de caráter passivo que se mantém imune à vida e às suas diversas manifestações, o que se impõe à Vontade Geral é um incessante vir a ser que converge para as fronteiras que encerram a unidade de sentido da vida sociopolítica dos homens em sua concreticidade histórico-cultural e econômico-social, perfazendo uma realidade que conjuga empirismo e idealidade e que longe de supor a ausência de participação ativa do povo na sua construção implica um movimento dinâmico-dialético que tende a sobrepujar os interesses particulares em nome da finalidade comum que se lhe está essencialmente atrelada.

À Vontade Geral o que se impõe não é senão um processo que encerra a realização das próprias determinações de um povo, o que implica a atribuição no que concerne ao indivíduo de uma condição que traz como fundamento o reconhecimento mútuo, para cujo acontecimento converge a vida ética e a sua substancialidade, que não se caracteriza, pois, como algo dado de uma forma acabada, mas no sentido que envolve um modo de relação baseado em uma atividade que guarda possibilidade de mudá-lo. Nesse sentido, o homem constitui-se, pois, como um ser em relação em face das determinações substanciais do conceito em uma perspectiva que encerra a virtude como uma correspondência lógica no que tange ao dever ético, o que se lhe mantém sob a égide de um princípio de adesão as raízes do qual não podem emergir senão da capacidade reflexiva, que consiste na base para o exercício de uma liberdade que não se circunscreve a um estado mas perfaz uma construção que, envolvendo os homens entre si e a coletividade, as partes e o todo, demanda uma articulação que requer uma igualdade substantiva, material, que confira viabilidade à sua instauração. 
capacidades reais dos indivíduos só poderão ser plenamente desenvolvidas em igualdade completa. Só quando houver igualdade desde o início para todos os homens em cima da terra, só então - salvaguardando os superiores direitos da solidariedade, que é e continuará a ser a principal base de toda a vida social: inteligência humana e bens materiais - se poderá dizer que todo o indivíduo é fruto do seu próprio esforço. Donde concluímos que, para que as capacidades individuais prosperem e não sejam mais impedidas de darem todos os seus frutos, é necessário, antes de mais nada, que todos os privilégios individuais, tanto políticos como econômicos, isto é, todas as classes, sejam abolidos. (BAKUNIN, 1979, p. 40, grifos do autor)

Se a finalidade da instituição do Estado consiste no bem comum, o que se impõe à direção das suas forças não é senão a Vontade Geral, tendo em vista a suposição envolvendo a oposição concernente aos interesses particulares e a necessidade de superá-la como condição originária acerca do estabelecimento da ordem social e política, que encerra em sua constituição a possibilidade de acordo em relação aos mesmos, caracterizandose aquilo que há de comum nestes como a base que possibilita a existência da própria sociedade, à medida que estabelece a coesão que a sua organização implica e perfaz um parâmetro para o exercício do governo.

Nesta perspectiva, se escapa ao sentido que envolve vontade de todos (maioria), o que cabe à Vontade Geral é uma condição que não se circunscreve às fronteiras de uma construção que traz em sua estrutura fins redutíveis aos indivíduos e aos interesses particulares que os caracterizam, à medida que o bem comum não consiste em uma mera coincidência com aquilo que, no tocante a si próprios, embora na qualidade de membros do corpo coletivo e moral em questão, os tais julgam como "bem", visto que, se a razão pública se caracteriza como abstrata, a Vontade Geral não consiste senão na encarnação da razão concreta e viva, perfazendo a transição da liberdade negativa para a positividade em um movimento que implica a própria constituição do corpo coletivo e moral enquanto tal.

Ao interesse comum o que se impõe, pois, não é senão a condição do indivíduo como membro do corpo coletivo e moral 
que emerge através do pacto, o que o implica necessariamente, tendo em vista que se a instituição da ordem social o pressupõe para ele converge simultaneamente em uma relação que exclui a correspondência da noção em questão com o estado de natureza, à medida que o que tem valor é que uma vez integrante de uma comunidade, sob a acepção de parte de uma totalidade concreta, se lhe escapa qualquer possibilidade de manifestação do interesse individual característico daquele modus vivendi.

Um novo tipo de indivíduo, eis a proposta que emerge da leitura rousseauniana, cuja perspectiva não se esgota nas fronteiras da transformação da sociedade como um todo, nem antes se detém na busca de uma ordem estatal legítima, conforme a pressuposição que advém da análise da transição do Estado Natural para o Estado Social, demandando uma dialética que se impõe às fronteiras que encerram a transformação dos fundamentos econômico-sociais e a reconstrução do homem enquanto tal no que concerne à sua relação com a coletividade. Tal processo emerge à medida que, se não propõe a supressão da propriedade privada ou a sua socialização propriamente dita, conforme defende a perspectiva marxiana, a leitura rousseauniana, identificando-a como a raiz da desigualdade social, impõe uma limitação que converge para a construção da igualdade material, que implica menos uma determinação da ordem política do que um condicionamento da própria organização social, mesmo porque, inexistindo ruptura hierárquica ou não entre ambas, a referida construção guarda

9 “'Ora, o povo como corpo, 'o soberano', não poderia querer senão o interesse geral, não poderia ter senão uma vontade geral. Enquanto cada um dos membros, sendo simultaneamente, em consequência do contrato, homem individual e homem social, pode ter duas espécies de vontade. Como homem individual, é tentado a perseguir, de acordo com o instinto natural, egoísta, o seu interesse particular. Mas o homem social que nele existe, o cidadão, procura e quer o interesse geral: trata-se de uma busca toda moral, feita no 'silêncio das paixões'. A liberdade - a liberdade natural transformada, desnaturada - é, precisamente, a faculdade que possui cada um de fazer predominar, sobre a sua vontade 'particular', a sua vontade 'geral', que apaga 'o amor de si mesmo' em proveito do 'amor do grupo' (B. de Jouvenel). Assim, obedecer ao soberano, ao povo em conjunto, é verdadeiramente ser livre." (CHEVALLIER, 1999, p. 167, grifos do autor) 
correspondência, em suma, com a noção de autogoverno ${ }^{10}$.

Se a Vontade Geral consiste em um processo éticojurídico de deliberação coletiva, o que se impõe à sua manifestação como um fenômeno histórico-cultural é a condição de imanência que a caracteriza em um movimento dinâmicodialético que demanda uma formação econômico-social que possibilite a emergência de valores e práticas, condutas e comportamentos, necessidades e objetivos que, tendo como fundamento o interesse comum, se lhe correspondam. A pressuposição que emerge, nessa perspectiva, implica a sua inviabilidade em face da ordem em vigor que, se requer a transformação dos homens enquanto indivíduos concretos que a formam, não pode prescindir do que se lhe antecipa, daquilo, pois, que lhe serve de fundamento para a sua existência coletiva, a saber, das relações socioprodutivas, à dinâmica das quais cabe introduzir princípios capazes de sobrepor ao capitalismo monopolista o sistema comunal através da instauração de um novo modo de intercâmbio.

Longe de se deter em questões que envolvem revolução e contrarrevolução, que caracterizam um dogmatismo contraproducente que escapa, inclusive, à leitura socialista pósmoderna, à medida que supõe a verticalização do poder, a autogestão $^{11}$ implica um fenômeno de transformação estrutural que, diferentemente, converge para a horizontalidade do poder, constituindo-se o povo o seu sinônimo efetivo. Cabe sublinhar que a referida perspectiva, em vigor na Europa em determinadas regiões em função da crise econômica, como também na América Latina (tal como o exemplo da Venezuela, entre outros), certamente não dispõe da simpatia de uma parcela da sociedade, cujo percentual encerra tanto os que se beneficiam da formação econômico-social em vigor quanto os que se mantém como

10 Alcança relevância, nesta perspectiva, a concepção que encerra que "o axioma fundamental e, para falar mais adequadamente, constitutivo da autogestão é, meridianamente, o da igualdade das pessoas." (GUILLERM; BOURDET, 1976, p. 46, grifos do autor)

11 Autogestão guarda correspondência com "a tradução literal da palavra servo-croata samoupravlje ('samo' sendo o equivalente eslavo do prefixo grego 'auto', e 'upravlje' significando aproximadamente 'gestão')." (GUILLERM; BOURDET, 1976, p. 11) 
reféns da condição de alienação se lhes atribuída pelo contexto histórico-cultural, que demanda a reavaliação da base da realidade socioprodutiva, para a qual a instauração de uma atividade como esta, que mobiliza "massas", torna-se fundamental e deve se tornar objeto de discussão ético-jurídica e econômico-política ${ }^{12}$.

\section{0 sistema autogestionário e a autodeterminação coletiva: a correlação envolvendo o político e o econômico}

O que é o governo? O governo é a economia pública, a suprema administração dos trabalhos e bens de toda a nação. (PROUDHON, 1975, p. 180)

À relação de dependência envolvendo as condições concretas da sua existência, que abrangem desde uma determinada estrutura de produção, a divisão social e tecnológica do trabalho ${ }^{13}$, até as instituições políticas, além dos valores e práticas, condutas e comportamentos, necessidades e objetivos que perfazem um arcabouço cultural, o que se impõe aos homens

12 Torna-se relevante, nesta perspectiva, recorrer ao argumento de Proudhon a respeito da contradição envolvendo a crítica da forma e dos atos do governo se o contexto implica a manutenção das condições constitutivas do poder: "Diz-se que o povo, nomeando os seus legisladores e através deles notificando a sua vontade ao poder, estará sempre em condições de deter as invasões deste último; diz-se que desta forma o povo desempenhará ao mesmo tempo o papel de príncipe e o de soberano. Eis em duas palavras a utopia dos democratas, a eterna mistificação com a qual eles enganam o proletariado.

Mas o povo faria leis contra o poder, contra o princípio de autoridade e de hierarquia - que é o princípio da própria sociedade, contra a liberdade e a propriedade? $\mathrm{Na}$ hipótese em que nos achamos isto é mais que impossível, é contraditório. E portanto a propriedade, o monopólio, a concorrência, os privilégios industriais, a desigualdade das fortunas, a preponderância do capital, a centralização hierárquica e esmagadora, a opressão administrativa e o arbítrio legal serão conservados; e como é impossível que um governo não atue no sentido de seu princípio, o capital permanecerá como antes o deus da sociedade e o povo, sempre explorado e sempre envilecido, nada mais ganhará, desta tentativa de soberania, senão a demonstração de sua impotência." (PROUDHON, 2003, p. 429)

13 "O Trabalho, dividindo-se segundo a lei que lhe é própria e que é a condição primeira de sua fecundidade, atinge a negação de seus fins e destrói-se a si mesmo; em outros termos: A divisão fora da qual não há mais progresso, nem riqueza, nem igualdade, subalterniza o operário, torna a inteligência inútil, a riqueza nociva e a igualdade impossivel." (PROUDHON, 2003, p. 181, grifos do autor) 
como seres autônomos e conscientes não é senão uma forma de autodeterminação que implica um processo que guarda possibilidade de promover a superação da alienação das capacidades humanas no contexto das relações sociais, a saber, a autogestão. Se a autogestão consiste em uma noção fundamental para a teoria e a práxis da "democracia econômica" (ou "democracia industrial"), constituindo-se, em suma, na base da "democracia participativa" ou do "socialismo autogerido", a sua emergência converge, tanto no âmbito produtivo (autogestão operária) quanto na esfera política (autogestão social), para as fronteiras que encerram a necessidade de ampliação do controle e do poder no interior das organizações sociais, perfazendo uma demanda popular que tende à corporificação através das formas que envolvem conselho de trabalhadores ${ }^{14}$ ou conselho de cidadãos.

Experiência social de autodeterminação coletiva, que implica tanto a esfera política quanto o âmbito econômico (trabalho), eis o que se impõe à autogestão, cujo sistema emerge como uma alternativa de produção que traz em sua organização princípios e estruturas não-capitalistas que, simultaneamente, convergem para operar em uma economia de mercado, guardando a possibilidade de se constituírem em empreendimentos capazes de superar em produtividade as empresas capitalistas de heterogestão, promovendo resultados econômico-sociais que envolvem do estímulo ao desenvolvimento econômico local à redução do nível de desigualdades estruturais, chegando a proporcionar para os seus membros, assim como para as comunidades adjacentes, benefícios que não se restringem à área econômica.

14 Convém esclarecer que os conselhos operários, segundo Anton Pannekoek, "não designa uma forma de organização fixa, elaborada de uma vez por todas, a qual só faltaria aperfeiçoar os detalhes; trata-se de um princípio, o princípio da autogestão operária das empresas e da produção. A realização deste princípio não passa, absolutamente, por uma discussão teórica referente aos seus melhores modos de execução. É uma questão de luta prática contra o aparato de dominação capitalista. Em nossos dias, por conselhos operários não se entende a associação fraternal que tem um fim em si mesma; conselhos operários quer dizer luta de classes (na qual a fraternidade tem seu lugar), ação revolucionária contra o poder do Estado.” (Apud BRICIANER, 1975, p. 310) 
Contrapondo-se ao capitalismo globalizado, a autogestão se impõe à construção de uma formação econômicosocial que não tende senão à igualdade substancial (concreta), para cujas fronteiras converge a participação política, tendo em vista o processo de socialização gerencial que envolve todas as esferas da vida social, abrangendo dimensões políticas, sociais, econômicas e culturais, a totalidade da estrutura social, em suma, à medida que, caracterizando-se como universalizante, implica a autodeterminação coletiva.

Guardando o sentido lato que implica, no tocante à organização econômica, uma forma democrática, que converge para uma estrutura constituída de vários níveis de conselho e assembleias, a autogestão envolve a socialização do poder gerencial empresarial no processo de organização do trabalho, possibilitando a superação da hierarquia que emerge da distinção entre o núcleo decisório e a esfera de execução, à medida que através de seus delegados os trabalhadores têm acesso ao poder deliberativo, escapando à condição de alienação vigente em um contexto de relações determinado pela racionalização tecnológico-organizacional.

Sobrepondo-se aos aspectos econômicos (ou industriais, fabris), a autogestão, não se circunscrevendo às referidas fronteiras, se impõe como um método de gestão social que guarda complementariedade no que tange a estas, constituindo, dessa forma, um arcabouço que encerra a articulação que envolve os pressupostos políticos, convergindo para uma construção que implica um sistema democrático radical que sob o horizonte rousseauniano consiste na transposição, nas esferas de participação, para o âmbito das estruturas concretas das atividades econômico-sociais de um mecanismo representativo do poder econômico-político, transformando a realidade social então vigente.

Conforme os princípios da inalienabilidade do poder de determinar as regras (isto é, a "soberania" do trabalho não como uma classe particular mas como condição universal da sociedade) e da delegação de papéis e funções sob regras bem específicas, definidas, flexivelmente distribuídas e adequadamente supervisionadas, o estabelecimento de uma 
forma socialista de tomada de decisão exigiria invadir e reestruturar radicalmente os domínios materiais antagônicos do capital. Um processo que deveria ir bem além do princípio da soberania popular inalienável de Rousseau e seu corolário delegatório. Ou seja, numa ordem socialista, o processo "legislativo" deveria ser fundido ao próprio processo de produção de tal modo que a necessária divisão horizontal do trabalho (...) fosse complementada em todos os níveis, do local ao global, por um sistema de coordenação autodeterminado do trabalho. Esta relação contrasta agudamente com a perniciosa divisão vertical do trabalho do capital, que é complementada pela "separação dos poderes" em um "sistema político democrático" alienado e inalteravelmente imposto às massas trabalhadoras. (MÉSZÁROS, 2011, pp. 828-829, grifos do autor)

Perfazendo as forças produtivas as capacidades produtivas da sociedade, as quais, não se circunscrevendo ao sentido tecnológico, implicam o aspecto social, abrangendo, além dos meios materiais de produção, as capacidades humanas, tanto físicas quanto conceituais, as relações de produção se caracterizam como as relações sociais que encerram a organização da produção e condicionam a alocação dos recursos e dos trabalhos, determinando, no que tange ao processo que envolve as atividades laborais, a sua disposição, como também, no referido complexo, a distribuição dos produtos, convergindo a combinação de ambas, a saber, as forças produtivas e as suas relações de produção, para a definição do padrão de relações de classe da sociedade e a sua dinâmica interna, o "modo de produção" $"$.

À socialização dos meios de produção o que se impõe,

15 Tendo em vista que, segundo Nicos Poulantzas, "as relações de produção e as ligações que as compõem (propriedade econômica/posse) traduzem-se sob a forma de poderes de classe que são organicamente articulados às relações políticas e ideológicas que os consagram e legitimam. Estas relações não se sobrepõem simplesmente às relações de produção já existentes, não atuam sobre elas retroativamente numa relação de exterioridade. Estão presentes na formação das relações de produção...(e) desempenham um papel essencial em sua reprodução, e desse modo o processo de produção e exploração é ao mesmo tempo processo de reprodução das relações de dominação/subordinação política ideológica. Deste dado fundamental decorre a presença do Estado, o qual materializa as relações político-ideológicas nas relações de produção.” (POULANTZAS, 1980, p. 32) 
pois, é a transformação da propriedade particular ou estatal em uma propriedade social, o que implica, no tocante aos meios de produção, na atribuição à sociedade como um todo da sua condição de pertencimento, cuja noção de posse se mantém, nessa perspectiva, atrelada a todos e a ninguém, cumprindo, neste contexto, a comunidade operária e o conselho de trabalhadores a função de gerência da produção, convergindo para um direito que se circunscreve à utilização e a apropriação dos resultados, e isso desde que não se lhe transponham os limites (ius abutendi), à medida que o objetivo da sua existência como tal é impedir o que caracteriza o conceito de propriedade que se lhe opõe, a propriedade privada, a saber, a exploração ${ }^{16}$.

Se a propriedade privada se caracteriza como a principal instituição da sociedade burguesa (capitalista), longe de reduzir a superação que a sua existência implica à expropriação de um proprietário individual em função da apropriação de um proprietário coletivo (conforme a forma histórica de apropriação concretizada na URSS), o que se impõe não é senão a emergência e redistribuição dos direitos que convergem para a constituição do direito da propriedade social, uma das referências fundamentais da estrutura da sociedade autogestionária.

Portanto, se o governo é economia, se tem por único objecto a produção e o consumo, a distribuição dos trabalhos e produtos, como se pode conciliar o governo com a propriedade? Se os bens são propriedades como é que os proprietários não seriam reis e reis despóticos, reis na proporção das suas faculdades de posse? E se cada proprietário é senhor absoluto na esfera da sua propriedade, como é que um governo de proprietários não seria um caos e uma confusão? (PROUDHON, 1975, p. 241)

A mudança das relações de produção capitalista não demanda senão, no tocante aos produtores, especificamente, e à

16 Conclusão para a qual converge o pensamento proudhoniano, que assinala: "Ora, a propriedade engendra necessariamente o despotismo, o governo do belo prazer, o reino de uma vontade libidinosa; isso faz de tal maneira parte da essência de propriedade que basta, para se convencerem, lembrar o que ela é e o que se passa à nossa volta. A propriedade é o direito de usar e abusar." (PROUDHON, 1975, p. 241, grifos do autor) 
sociedade, em suma, a apropriação do produto do trabalho, a assimilação dos meios de produção ${ }^{17}$, enfim, consistindo a desapropriação em questão (socialista) na repartição dos diferentes direitos de decisão entre as coletividades, convergindo, seja no âmbito empresarial (privado), seja na esfera social, para as fronteiras que encerram a interdependência envolvendo a economia e a política. A autogestão emerge, nessa perspectiva, através do pressuposto que defende a legitimação do direito de intervenção e do poder decisório no que concerne ao funcionamento e à estrutura organizacional das empresas (que devem alcançar uma condição de ampla abertura em face da sociedade), à medida que a alteração da composição de um conselho administrativo, embora por intermédio de uma gestão democrática, não guarda capacidade de promover a modificação da questão referente ao poder e à situação do seu exercício no contexto dos trabalhadores.

Se um sistema autogestionário, no que tange à origem do poder e ao processo de centralização, demanda a construção de mecanismos transparentes, o que se impõe, simultaneamente, não é senão a necessidade que implica a descentralização do seu exercício, à medida que converge para conferir às coletividades às quais competem os assuntos em pauta a devida capacidade decisória, deliberativa, que se lhe é distribuída, pois, maximizadamente. Torna-se relevante, nesta perspectiva, que envolve uma planificação democrática, a circulação das informações e a possibilidade das opções, tendo em vista uma conjuntura caracterizada pela inter-relação de forças antagônicas, a cuja realidade deve se sobrepor um planejamento que, emergindo como um ato político, guarde correspondência com determinadas fronteiras sociais que encerram como base uma economia contratual.

À transformação das relações sociais, para a qual tende a

17 Tendo em vista que "um dos pressupostos do trabalho assalariado e uma das condições históricas do capital é o trabalho livre e a troca de trabalho livre por dinheiro, com o objetivo de reproduzir o dinheiro e valorizá-lo; de o trabalho ser consumido pelo dinheiro - não como valor de uso para o desfrute, mas como valor de uso para o dinheiro. Outro pressuposto é a separação do trabalbo livre das condições objetivas de sua efetivação — dos meios e do material do trabalho." (MARX, 1985, p. 65, grifos meus) 
mudança econômica, o que se impõe, destacando o princípio político no tocante à autogestão, é a teoria da democracia direta, à medida que, se a autogestão implica uma gestão democrática das estruturas e decisões econômicas por parte da sociedade, convergindo para as fronteiras que atrelam ao conceito um caráter político, não se lhe escapa, contudo, o aspecto econômico, que emerge através da análise que traz como base o operariado e as relações hierárquicas da estrutura fabri1 ${ }^{18}$, perfazendo uma perspectiva que correlaciona a formação econômica e os meios de poder, cujo exercício, contudo, se em favor das indústrias ou se em benefício do Estado, torna-se necessário descobrir, se the conferindo publicidade, tendo em vista que

o poder, instrumento da força coletiva, criado na sociedade para servir de mediador entre o trabalho e o privilégio, encontra-se encadeado fatalmente ao capital e dirigido contra o proletariado. Nenhuma reforma política pode resolver esta contradição pois, como os próprios políticos o confessam, tal reforma apenas daria mais extensão e energia ao poder e, a menos que se derrube a hierarquia e se dissolva a sociedade, o poder não poderia tocar nas prerrogativas do monopólio. O problema pois consiste, para as classes trabalhadoras, não em conquistar, mas sim em vencer ao mesmo tempo o poder e o monopólio, o que significa fazer surgir das entranhas do povo, das profundezas do trabalho uma autoridade maior, um fato mais poderoso, que envolva o capital e o Estado e que os subjugue. Toda a proposição de reforma que não satisfaça a esta condição será apenas um flagelo a mais, uma verga em sentinela, virga vigilantem diria um profeta, que ameaça o proletariado. (PROUDHON, 2003, p. 434)

Caracterizando-se como uma transformação radical que não se circunscrevendo à esfera econômica converge para o

18 Alcança relevância, nessa perspectiva, a proposta de Rosa Luxemburgo acerca da criação de uma nova ordem na esfera do processo produtivo que seja capaz de se sobrepor às estruturas hierárquicas e ao monopólio dos meios de produção que caracterizam o sistema capitalista, convergindo para a sua transformação: "Eleições, em todas as fábricas, de conselhos de fábrica que, de acordo com os conselhos operários, deverão administrar todos os assuntos internos da empresa, as condições de trabalho, controlar a produção e, finalmente, assumir a direção da empresa." (LUXEMBURGO, 1991, p. 108) 
âmbito político, a autogestão se sobrepõe, nesta perspectiva, à concepção que encerra o referido exercício ao poder de uma classe especializada, tornando-o objeto de todos os homens, indistintamente, o que implica, em suma, uma sociedade igualitária ${ }^{19}$. E isto ocorre à medida que, acenando com a possibilidade que envolve a constituição de uma sociedade sem classes, o referido sistema se impõe ao viés mercadológico que caracteriza a organização econômico-social vigente e à estrutura burocrática corporificada pelo Estado que, emergindo como um organismo hipercentralizado, não demanda senão uma conversão que guarde capacidade de se lhe atribuir a função de núcleo de regulação social, tendo em vista a pressuposição que implica a autonomia da ordem sociopolítica.

\section{O sistema autogestionário e a sua concreticidade histórico-cultural e econômico-social: movimentos cooperativos e comunas socialistas}

A Comuna - a reabsorção, pela sociedade, pelas próprias massas populares, do poder estatal como suas próprias forças vitais em vez de forças que a controlam e subjugam, constituindo sua própria força em vez da força organizada de sua supressão -, a forma política de sua emancipação social, no lugar da força artificial (apropriada por seus opressores) (sua própria força oposta a elas e organizadas contra elas) da sociedade erguida por seus inimigos para sua opressão. A forma era simples, como o são todas as coisas grandiosas. (MARX, 2011, p. 129)

Se o kolkhoz, ou fazenda coletiva russa, que objetivava resolver os problemas da produção agrícola na antiga União Soviética, assim como o empreendimento organizado por Julius Nyerere nos anos 1960 na aldeia de Ujamaa, na Tanzânia, representa a incompatibilidade entre a cooperação e as formas estatistas de transformação social, as iniciativas de autogestão de operários na ex-Iugoslávia e as comunas chinesas perfazem

19 De acordo com a perspectiva que advoga "uma transformação radical da sociedade que tenha como fim a abolição de classes quer do ponto de vista econômico, quer do ponto de vista político, e uma organização em que todos os homens nascerão, se desenvolverão, se instruirão e usufruirão dos bens necessários à vida, em condições de igualdade para todos.” (BAKUNIN, 1979, p. 6) 
experiências positivas de gestão coletiva, à medida que estas últimas, por exemplo, constituídas depois do Grande Salto para a Frente, em 1958, tanto nos distritos rurais quanto urbanos, convergiram para a organização e a regulação da produção do consumo, da defesa e da educação, configurando-se, contudo, a introdução dos modos ocidentais de modernização capitalista um risco no tocante à manutenção da tendência em relação aos resultados substanciais que, parcialmente embora, acenam, em suma, com a realização da utopia comunista ${ }^{20}$.

Nesta perspectiva, em um contexto que encerra aproximadamente 100 milhões de pessoas integradas aos movimentos cooperativos na Europa e na América do Norte, o Complexo de Mondragon, na região basca do norte da Espanha, fundado em 1958 por Arizmendi, um padre socialista, se caracteriza como uma experiência que converge para assinalar a possibilidade de eficiência no que tange à implementação e desenvolvimento da "cultura cooperativa" e a aplicação dos princípios de filiação voluntária e controle democrático. Tal processo se impõe à medida que, trazendo uma estrutura que implica a disponibilização de uma rede de atividades, serviços e negócios que abrange desde a área bancária até o setor habitacional, do campo da educação à esfera do bem-estar social e o ramo de bens de consumo, emprega cerca de 19 mil operários/proprietários em mais de 100 cooperativas.

Se o impulso ético, idealista, por vezes, caracteriza o cooperativismo, que emerge como um sistema alternativo no que concerne ao capitalismo, à medida que se impõe de baixo para cima, sobrepondo ao individualismo burguês a reciprocidade e a solidariedade social, a sua prática não converge senão para transformar as relações humanas, haja vista que, embora baseada

20 "O conceito de utopia é um conceito histórico e se refere a projetos de transformação social cuja realização é considerada impossível. Mas por quais razões são tais projetos considerados como irrealizáveis? Geralmente, quando se discute sobre o conceito de utopia, fala-se de irrealizabilidade como impossibilidade de traduzir em fatos concretos o projeto de uma nova sociedade, na medida em que os fatores subjetivos e objetivos de uma dada situação social se opõem à sua transformação. Tratase da chamada imaturidade das condições sociais, que obstaculiza a realização de um determinado fim.” (MARCUSE, 1969, p. 15) 
no bem comum, não deixa de pressupor a concorrência de interesses privados na sua construção. Guardando, por sua vez, o sentido de cooperação mútua, tende se não a eliminar completamente os referidos interesses a reduzi-los gradualmente à acepção de manifestações aleatórias sem a força plasmadora, coesiva, que determina o jogo econômico-político regido pelo peso da maioria no âmbito da formação que se impõe como não mais do que liberal-democrática.

Nessa perspectiva, o que se impõe é a superação das estruturas burocráticas cuja funcionalidade, escapando ao controle social, permanece à mercê da corrupção endêmica que as caracterizam, o que demanda uma consciência e uma organização popular capazes de implementar mudanças estruturais a partir da base da sociedade, convergindo para as fronteiras que encerram relações socioprodutivas baseadas na horizontalidade, caracterizadas pela cooperação e pela solidariedade, perfazendo um conjunto de comportamentos que, emergindo das atividades atreladas às trocas, se sobrepõe ao horizonte da razão utilitária. Tal condição implica em um horizonte que abrange a empatia, a dádiva, a reciprocidade, o altruísmo, em suma, determinando motivações que não tendem a engendrar senão relações que, divergindo, no tocante aos valores que regem o intercâmbio mercantil, se lhe guardam incompatibilidade, acenando com a emergência de uma lógica anticapitalista, a saber, que sobreponha aos produtos as atividades, se lhes atribuindo o caráter fundamental que lhes cabe na inter-relação constitutiva que se impõe ao complexo da autogestão econômica.

Se as experiências pós-capitalistas não convergiram para a alteração das relações de produção nem se contrapuseram efetivamente à alienação do trabalho, à medida que o que se impunha não era senão o desenvolvimento das forças produtivas, o aspecto material da sociedade então emergente (oriunda da Revolução de Outubro), a relevância dos processos autogestionários da Iugoslávia se mantém reduzida à esfera das unidades produtivas, tendo em vista a sua incapacidade de alcançar o horizonte que implica a macroeconomia, cuja gestão permanecia sob o poder do partido único em um contexto que 
não possibilitava a liberdade de expressão, o debate, a organização, e que, no que concerne à regulação econômica, conferiu ao mercado um protagonismo que não acarretou menos do que assimetrias e ambiguidades que influenciaram a deflagração da implosão iugoslava.

Se a organização democrática dos movimentos sociais e dos partidos socialistas, a economia solidária, a conquista de espaços democráticos na mídia, o desenvolvimento dos serviços sociais de educação e saúde, o orçamento participativo, entre outras iniciativas, não se impõem senão como medidas que convergem para a instauração da ordem socialista, o que se lhe impõe, contudo, no que tange à mudança de patamar, é a emergência de rupturas (saltos qualitativos) que, impedindo a tendência ao retrocesso da economia, encaminhem para a superação da hegemonia do capital ${ }^{21}$.

Criação, desenvolvimento e consolidação de experiências que implicam o exercício da democracia direta ou autogestão política, eis o processo que se impõe à Venezuela desde a promulgação da Constituição de 1999, convergindo, através da inter-relação que envolve os Conselhos Comunais (Ccs) e as Comunas Socialistas, para a superação do modelo estatal burguês, à medida que constituem instâncias que encerram valores, práticas e modos de gestão que, perfazendo uma estrutura identitária de poder que traz como horizonte o fundamento histórico-cultural e político-social local, possibilita a construção de um espaço participativo encarregado tanto da definição das prioridades da comunidade como da elaboração de projetos que visem a solução dos problemas, como também no tocante à sua

21 "Como vimos, o conceito de capital - a origem — implica dinheiro como ponto de partida e, portanto, implica a existência de riqueza em forma de dinheiro. Está igualmente implícita sua procedência da circulação; o capital surge como o produto da circulação. A formação do capital, portanto, não se origina da propriedade da terra (embora possa derivar dos arrendatários agrícolas na medida em que sejam, também, comerciantes de produtos agropecuários), nem das corporações (embora estas constituam, também, uma possibilidade) mas da riqueza mercantil e usurária. Porém, os comerciantes e usurários somente encontram condições que permitem a compra de trabalho livre quando este foi separado das condições objetivas de sua existência, em consequência de um processo histórico. Aí, torna-se possível, também, comprar as próprias condições.” (MARX, 1985, p. 101, grifos do autor) 
execução e controle. Além de deter a capacidade de autogestão política, as Comunas Socialistas se caracterizam como novas delimitações territoriais que concentram unidades socioprodutivas sob a direção daqueles que assumem as funções político-administrativas institucionais, a saber, os trabalhadores, aos quais é delegada, em suma, a propriedade e a administração dos meios de produção material ${ }^{22}$.

Carregando a finalidade de desenvolver e consolidar a forma político-social que corporifica o poder popular do Estado Comunal e se impõe como fundamento que guarda a possibilidade de convergir para a emergência de uma sociedade socialista, as Comunas $^{23}$ se caracterizam como instâncias que, inter-relacionadas

22 À experiência do processo de superação do modelo estatal burguês, implementada pelo governo de Hugo Chávez (1999-2013) sob a designação de "Revolução Bolivariana", cabe impor a sua crítica em relação ao sistema de representação parlamentar que, baseada na perspectiva de Rousseau, contrapõe à ordem existente, segundo o registro de Mészáros, "a ideia segundo a qual 'o povo soberano deve se transformar no objeto e no sujeito do poder. Chegamos a um ponto de não retorno e não nos é permitido retroceder. Para os revolucionários esta opção não pode ser negociável"'. Liderando na ocasião o Movimiento Bolivariano Revolucionário - MBR-200 (1993), Chávez defende o projeto de uma mudança radical da estrutura institucional, como Mészáros assinala: “O poder eleitoral do estado federal se tornará o componente político-jurídico pelo qual os cidadãos serão depositários da soberania popular, cujo exercício permanecerá daqui para frente realmente nas mãos do povo. O poder eleitoral será estendido a todo o sistema sociopolítico da nação, estabelecendo os canais para uma verdadeira distribuição policêntrica de poder, deslocando o poder do centro para a periferia, aumentando o poder efetivo da tomada de decisão e a autonomia das comunidades e municipalidades particulares. As Assembleias Eleitorais de cada municipalidade e estado elegerão Conselhos Eleitorais que possuirão um caráter permanente e funcionarão com independência absoluta dos partidos políticos. Eles serão capazes de estabelecer e dirigir os mecanismos mais diversos de democracia direta: assembleias populares, referendos, plebiscitos, iniciativas populares, vetos, revogação, etc. ... Assim, o conceito de democracia participativa será transformado em uma forma na qual a democracia baseada na soberania popular se constitui como a protagonista do poder. É precisamente nestas fronteiras que temos que traçar os limites de avanço da democracia bolivariana. Então nós deveremos estar muito perto do território da utopia.” (MÉSZÁROS, 2011, p. 830, grifos do autor)

23 Instaurando um regime de autogestão operária, a Comuna de Paris, segundo Ernst Mandel, caracteriza-se como "um primeiro exemplo do processo de revolução permanente" (1979, p. 16), consistindo em uma forma política da emancipação social que contrapõese ao estado bonapartista: "A Comuna era formada por conselheiros municipais, escolhidos por sufrágio universal nos diversos distritos da cidade, responsáveis e com mandatos revogáveis a qualquer momento. A maioria de seus membros era naturalmente formada de operários ou representantes incontestáveis da classe operária. 
entre si através da articulação e integração que se lhes cabe realizar, encerram funções que implicam o autogoverno, à medida que, disponibilizando recursos institucionais para a elaboração, execução e controle da gestão pública, oportuniza ao povo o exercício direto do poder e viabiliza a construção de um modelo econômico que traz como base a propriedade social e as suas empresas. Tal condição se impõe haja vista que, além dos Conselhos Comunais, a estrutura administrativa das Comunas tem em sua composição aquelas que ou estão sob o poder dos trabalhadores associados, que perfazem o tipo direto, ou são estatais, propriamente, detendo o tipo indireto, constituindo, em suma, um sistema que em função das necessidades coletivas implica um conjunto de relações de produção, distribuição, intercâmbio e consumo de bens e serviços, tanto quanto de conhecimentos, cuja organização objetiva, por intermédio de um planejamento estratégico, democrático e participativo, a instauração de um processo que não tende senão a se sobrepor à divisão social do trabalho ${ }^{24}$, a saber, a autogestão produtiva.

A Comuna devia ser não um corpo parlamentar, mas um órgão de trabalho, Executivo e Legislativo ao mesmo tempo. Em vez de continuar a ser o agente do governo central, a polícia foi imediatamente despojada de seus atributos políticos e convertida em agente da Comuna, responsável e substituível a qualquer momento. O mesmo se fez em relação aos funcionários de todos os outros ramos da administração. Dos membros da Comuna até os postos inferiores, o serviço público tinha de ser remunerado com salários de operários. Os direitos adquiridos e as despesas de representação dos altos dignitários do Estado desapareceram com os próprios altos dignitários. As funções públicas deixaram de ser propriedade privada dos fantoches do governo central. Não só a administração municipal, mas toda iniciativa exercida até então pelo Estado foi posta nas mãos da Comuna." (MARX, 2011, pp. 56-57)

24 Convém esclarecer que, guardando correspondência com a divisão social do trabalho e o seu caráter funcional, a divisão hierárquica do trabalho converge para o processo de reprodução do capital, segundo a leitura de Mészáros, que esclarece que "esta imposição da divisão social hierárquica do trabalho como força cimentadora mais problemática - em última análise, realmente explosiva - da sociedade é uma necessidade inevitável. Ela vem da condição insuperável, sob o domínio do capital, de que a sociedade deva se estruturar de maneira antagônica e específica, já que as funções de produção e de controle do processo de trabalho devem estar radicalmente separadas uma da outra e atribuídas a diferentes classes de indivíduos. Colocando de forma simples, o sistema do capital - cuja raison d'être é a extração máxima do trabalho excedente dos produtores de qualquer forma compatível com seus limites estruturais - possivelmente seria incapaz de preencher suas funções sociometabólicas de qualquer outra maneira. Por outro lado, nem mesmo a ordem feudal institui esse tipo de separação radical entre 
Consistindo, no tocante ao sistema capitalista, em uma proposta alternativa de autogestão política e econômica, as Comunas Socialistas da Venezuela se impõem como uma possibilidade de superação da democracia representativa através da instauração de uma nova forma de Estado, governo e sociedade que, corporificada pelos Conselhos Comunais, converge para a viabilização do exercício da democracia participativa, perfazendo o que se designa como nueva geometría del poder, que implica uma nova estrutura institucional que, transferindo a administração e gestão pública para as comunidades, possibilita o controle dos meios de produção sob o regime de propriedade social por parte dos trabalhadores, configurando um processo que pretende sobrepujar o modo de produção característico do capitalismo, que traz como fundamento a exploração do trabalho. Dessa forma, encerrando a capacidade de promover a satisfação das necessidades coletivas, os recursos excedentes da atividade econômica das organizações socioprodutivas do sistema econômico comunal não se destinam senão, por meio de um fundo criado para reuni-los, ao investimento e reinvestimento social, a fim de contribuir, dessa forma, para o desenvolvimento integral do país, conforme prevê a Lei Orgánica del Sistema Económico Comunal de 2010, descortinando um horizonte que acena com a reconstituição da unidade que envolve a esfera produtiva e o âmbito político, estabelecendo uma relação entre o poder e a base social capaz de engendrar um modo de ação política e uma estrutura de intercâmbios socioeconômicos e políticos determinada pela própria massa.

\section{Aspectos Conclusivos}

A incompatibilidade envolvendo democracia e pluralismo, que emerge da leitura rousseauniana em função da sua

o controle e a produção material. Apesar da completa sujeição política do servo, que o priva da liberdade pessoal de escolher a terra em que trabalha, no mínimo ele continua dono de seus instrumentos de trabalho e mantém um controle não formal, mas substantivo, sobre boa parte do processo de produção em si." (MÉSZÁROS, 2011, p. 99, grifos do autor) 
oposição no tocante à organização de associações particulares no âmago da sociedade, relacionada à perspectiva que sobrepõe, no que concerne à Vontade Geral, a voz da consciência ao debate público, tanto quanto à objeção quanto à representação, converge para caracterizar como anacrônica a composição institucional da democracia, tendo em vista a necessidade que encerra seja a superação das estruturas burocráticas da ordem em vigor no âmbito político, seja a emergência de uma lógica anticapitalista na esfera econômica, a saber, que sobreponha aos produtos as atividades, se lhes atribuindo o caráter fundamental que lhes cabe na inter-relação constitutiva que se impõe ao complexo da autogestão econômica.

À condição de soberano, que ao povo o contrato rousseauniano necessariamente se lhe atribui, o que se impõe, no tocante ao exercício do poder, é a manifestação daquilo que, sobrepondo-se ao privado, ao particular, expresse o interesse comum, a saber, a Vontade Geral, a qual, longe de guardar possibilidade de ser construída através da imposição de uma esfera independente mediante um processo coercitivo, não emerge senão por intermédio da formação econômico-social e da ética que lhe é imanente ${ }^{25}$. $\mathrm{E}$ isto tendo em vista que se o modo de produção relativo caracteriza o sistema capitalista, no âmbito do qual os grupos dominantes impõem ao Estado, em nome do livre mercado, os seus interesses, convergindo para a questão que implica quem se apropria realmente dos meios de poder, o modo de produção absoluto perfaz a estrutura socialista, para a qual tende um planejamento estatal, um sistema de planificação que coloca em questão, em suma, o papel e o estatuto social das esferas burocráticas, à medida que o problema não consiste senão em saber quem planifica, tanto quanto o nível em que esta operação ocorre, afinal.

25 "Se a forma coercitiva de sociedade existente até agora desmoronar e for substituída por uma forma livre de comunidade política e ética - uma forma na qual todos, em vez de estarem submetidos à arbitrariedade dos outros, reconhecem, aprovam e acatam como a sua própria apenas a vontade geral -, então a hora da redenção chegou. Mas essa redenção espera em vão por ajuda exterior. Nenhum Deus nos pode enviá-la; o homem deve sim se transformar no seu próprio salvador e, no sentido ético, no seu criador." (CASSIRER, 1999, p. 74) 
Propriedade privada, divisão do trabalho,
burocratização, desenvolvimento tecnológico, empresas multi/transnacionais - eis os eixos que se inter-relacionam no âmbito da civilização ocidental, caracterizando-se como pressupostos em oposição aos quais a teoria autogestionária se articula, perfazendo a natureza essencialmente contestadora da noção que se impõe ao referido conceito, a saber, "cooperação", em suma, uma relação que envolve "comunismo" e "socialismo", tendo em vista o viés anticapitalista para o qual convergem, implicando a supressão do capitalismo e do estatismo a construção de um conjunto autogestionado de cooperativas que, participando de uma estrutura de associação que tem como fundamento uma relação igualitária, traz como base organizacional um plano que encerra a soma de necessidades e desejos, à medida que

enquanto houver um certo número de homens economicamente privilegiados, um modo e bens particulares de vida que não são os da classe operária; enquanto houver um número mais ou menos considerável de indivíduos que herdem, em diferentes proporções, capitais ou terras que não tenham produzido pelo seu próprio trabalho, enquanto a maioria dos trabalhadores não herdam nada; enquanto o juro do capital e a renda da terra permitirem mais ou menos a esses indivíduos privilegiados viverem sem trabalhar; e supondo mesmo, o que, em semelhantes condições, não é admissível, - supondo que na sociedade todos trabalham, quer seja por obrigação, quer por gosto, mas que uma classe da sociedade, graças à sua posição econômica e, por isso mesmo, social e politicamente privilegiada, possa dedicar-se exclusivamente ao trabalho intelectual, enquanto a maioria esmagadora dos homens tem de alimentar-se com o trabalho dos seus braços; numa palavra, enquanto todos os indivíduos humanos não encontrarem na sociedade os mesmos meios de sustento, educação, instrução, trabalho e felicidade, - a igualdade política, econômica e social é completamente impossível. (BAKUNIN, 1979, p. 17, grifos do autor)

Redução dos níveis de produção, emprego e inversão tecnológica, eis a consequência que se impõe a uma empresa coletivizada, à medida que a maximização do bem-estar de todos 
os trabalhadores tende a comprometer a lucratividade e impedir os investimentos que a economia demanda, segundo a perspectiva liberal, que defende a capacidade do mercado e a lei da oferta e da procura no tocante a administração dos recursos disponíveis em detrimento de uma sociedade autogestionada, caracterizada como uma estrutura ineficiente, cuja efetivação converge para uma situação contraditória, visto que a crescente tecnicização da organização social, que sobrepõe a tecnocracia ao caráter político das decisões, limitando a competência do cidadão, não o impossibilita senão de exercer o pressuposto da sua condição, a saber, a soberania.

Se a experiência de autogestão na Iugoslávia, contrariando a suposição da crítica liberal, não converge senão para assinalar que a supressão dos princípios da racionalidade taylorista não afeta negativamente o nível de produtividade, à limitação da competência do cidadão que a crescente tecnicização da organização social acarreta o que se impõe é a distinção entre dois tipos de informação, a saber, aquela que, guardando caráter político, dirige as ações coletivas (generalizada) e aquela que, implicando um resultado específico, demanda um conteúdo técnico (especializada). Dessa forma, não havendo possibilidade acerca da centralização em uma dessas fronteiras da decisão no que tange à construção da informação e a sua consequente propagação como tal em todos os níveis da sociedade, torna-se imprescindível o processo de socialização de suas condições de produção, tanto quanto dos seus meios, além dos próprios instrumentos da sua organização, o que reivindica uma ampla circulação que, sobrepondo-se à perspectiva piramidal e elitista, possibilite o acesso ao núcleo decisório das coletividades.

Nessa perspectiva, o que se impõe à sociedade autogestionária é um processo que não emerge senão através de novas relações de poder envolvendo as microinstituições (organizações de massa, comitês de bairro, clubes juvenis, entre outras), implicando o desenvolvimento de contrainstituições como uma possibilidade que emerge das teorias autogestionárias e converge para se sobrepor à relação instável envolvendo instituinte e instituído, pretendendo gerar acontecimentos 
simbólicos que se imponham à consciência coletiva e individual a respeito das relações de poder, transpondo as fronteiras que se detêm no dualismo que implica preparação e ação, reforma ou revolução, tendo em vista que

(o) sistema social socialista não deve e nem pode ser senão um produto histórico, nascido da própria escola da experiência, nascido na hora da sua realização, resultando do fazer-se da história viva (...). O socialismo, por sua própria natureza, não pode ser outorgado nem introduzido por decreto. Ele pressupõe uma série de medidas coercitivas, contra a propriedade, etc. Pode-se decretar o negativo, a destruição, mas não o positivo, a construção. (LUXEMBURGO, 1991, p. 92)

Se o caráter revolucionário do pensamento social do século XIX não se impõe senão através da oposição que envolve Estado e "sociedade civil", a sua emergência afirma-se em Marx, tanto quanto em Proudhon, à medida que a distinção que a formulação hegeliana propõe se circunscreve às fronteiras do conceito que converge para o âmbito jurídico, no qual a evocação que alcança relevância implica a diferença entre as sociedades que não se mantêm sob o domínio de um poder centralizado (societas sine imperio) e os Estados que detêm autoridade e poder. Tal perspectiva, que perfaz a leitura que pretende demonstrar a condição de parte do Estado da "sociedade civil" (que, dessa forma, se lhe permanece sujeito), converge para a transformação ou para a deformação da referida noção, tendo em vista que, se sublinha o Estado como ideia e ideal da sociedade, relaciona à imagem moral que sugere a sua possibilidade de consolidação.

À "sociedade civil" a leitura hegeliana impõe uma concepção que a encerra como a soma das vontades individuais atomizadas que, nesta acepção, se mantém reduzida à condição que envolve não mais do que o interesse geral, do qual não se lhe distingue, acenando, por sua vez, com uma contraposição à Vontade Geral que emerge da interpretação rousseauniana. Nesse sentido, caracteriza-se como imprescindível para a compreensão da utilização da referida expressão neste contexto perspectivacional, que assinala o processo de subversão se lhe atribuído pela evocação da sua "ideia" (da "sociedade civil", em 
suma, que condensa "a projeção de ideias interiores imaginárias"), a crítica de Marx ao raciocínio em questão, que guarda a suposição de que a sociedade real, viva, que inter-relaciona em sua constitutividade tensões e classes, interesses múltiplos e divergentes e diversas formas de sociabilidade, o povo, em última instância, não representa a realidade, senão a ideia dessa sociedade que o Estado exprime ${ }^{26}$.

Às forças coletivas criadoras, que se mantêm em condição de inatividade pelo Estado ou pela desigualdade econômica, se impõe a superação da alienação que a existência desta forma institucional como tal implica, à medida que não é sem razão que se lhe cabe uma identificação com a burguesia, convergindo para uma noção que, acenando com a constituição extrassocial do poder público, caracteriza o Estado como uma realidade que permanece à margem da sociedade civil. Não se lhe alcançando a integração, a forma institucional em questão se configura, em última instância, como despótica, usurpadora, passível de destruição, cuja necessidade a leitura de Proudhon assinala, propondo a instauração da democracia industrial, que não guarda senão a possibilidade de concretização da autonomia da força

26 Nesta perspectiva, cabe recorrer ao diagnóstico de Marx, que esclarece: "Sociedade civil e Estado estão separados. Portanto, também o cidadão do Estado está separado do simples cidadão, isto é, do membro da sociedade civil. O cidadão deve, pois, realizar uma ruptura essencial consigo mesmo. Como cidadão real, ele se encontra em uma dupla organização, a burocrática - que é uma determinação externa, formal, do Estado transcendente, do poder governamental, que não tangencia o cidadão e a sua realidade independente - e a social, a organização da sociedade civil. Nesta última, porém, o cidadão se encontra, como homem privado, fora do Estado; ela não tangencia o Estado político como tal. A primeira é uma organização estatal, para a qual ele sempre dá a matéria. A segunda é uma organização social, cuja matéria não é o Estado. Na primeira, o Estado se comporta como oposição formal ao cidadão; na segunda, o cidadão se comporta como oposição material ao Estado. Portanto, para se comportar como cidadão real do Estado, para obter significado e eficácia políticos, ele deve abandonar sua realidade social, abstrair-se dela, refugiar-se de toda essa organização em sua individualidade; pois a única existência que ele encontra para sua qualidade de cidadão do Estado é sua individualidade nua e crua, já que a existência do Estado como governo está completa sem ele e que a existência dele na sociedade civil está completa sem o Estado. Apenas em contradição com essas únicas comunidades existentes, apenas como indivíduo, ele pode ser cidadão do Estado. Sua existência como cidadão do Estado é uma existência que se encontra fora de suas existências comunitárias, sendo, portanto, puramente individual." (MARX, 2010, pp. 94-95, grifos do autor) 
produtora, ou seja, a autogestão ${ }^{27}$.

Se a emergência dos conselhos de fábrica no início do século XX guarda correspondência com a "democracia industrial" de Proudhon, a demanda que se impõe ao sindicalismo revolucionário converge, no âmbito dos países europeus e sob a égide do "luxemburguismo"28, para as fronteiras da autogestão, que traz como fundamento uma ideia do direito social que encerra a noção de "sociedade civil" e de "multiplicidade social". Tal noção acena com uma realidade jurídica diversificada que se contrapõe à leitura de direito que mantém raízes no arcabouço hegeliano e que implica, sob a égide de uma microssociologia dinâmica, a possibilidade de que os grupos, concernente ao poder e às técnicas, exerçam o seu controle, desenvolvendo novas formas para o êxito da referida atividade.

A relação envolvendo soberania e Vontade Geral não se impõe senão através de um processo dialético que, guardando raízes no horizonte da organicidade, acena com uma complexidade estrutural cuja constitutividade encerra uma multiplicidade de forças antagônicas, convergindo para as fronteiras da autogestão, que longe de constituir o Estado constitui-se por si o Estado, detentor de um poder que não emerge originariamente como extrassocial, mesmo que

27 "Proudhon nunca empregou o termo autogestão, que é um termo recente; todavia, ele empregou o seu conteúdo, não restringindo o sentido de uma sociedade autônoma à simples administração de uma empresa pelo seu pessoal. Ele deu, pela primeira vez, à sua concepção, o significado de um conjunto social de grupos autônomos, associados tanto nas funções econômicas de produção quanto nas funções políticas. A sociedade autogestionária, em Proudhon, é a sociedade organicamente autônoma, constituída de um feixe de autonomias de grupos se auto-administrando, cuja vida exige coordenação, mas não hierarquização”. (MOT'TA, 1981, p. 133)

28 Contrapondo-se ao monopólio dos meios de trabalho exercido através de uma classe e à condição que, se lhe correspondendo, implica o trabalho assalariado, Rosa Luxemburgo defende que "os meios de trabalho não devem mais ser monopólio de uma classe, mas tornar-se bem comum", além de propor a "regulamentação da produção e repartição dos produtos no interesse da coletividade" (1991, p. 101), convergindo para a conclusão de que "a essência da sociedade socialista consiste no seguinte: a grande massa trabalhadora deixa de ser uma massa governada, para viver ela mesma a vida política e econômica na sua totalidade, e para orientá-la por uma autodeterminação consciente e livre.” (1991, p. 103) 
aparentemente seja relegado a tal condição ou venha assumi-la como imposição de uma das suas partes constitutivas, o que, em última instância, não se caracteriza senão como uma ruptura. Dessa forma, pois, o sistema autogestionário, em contraposição ao arcabouço que encerra o antagonismo envolvendo Estado e sociedade (ou, segundo a referida dicotomia, o político e o social), constitui um sistema que encerra elementos que, interrelacionados, legislam em causa própria, esvaziando, desse modo, o sentido que carrega a vontade de todos (maioria), se lhe sobrepondo pela concepção que pretende a reconstrução da sociedade civil e a sua transformação na verdadeira infraestrutura social, que demanda, em última instância, a morte das instituições, a sua transformação ou a inversão de seu sentido, conforme a tendência instaurada pelo poder político autogestor, ao qual cabe possibilitar à sociedade a liberdade de autoinstituição.

Se a leitura liberal atribui à democracia a condição que a circunscreve a uma forma constitucional capaz de assegurar, em suma, os direitos aos indivíduos, cumprindo a função de proteger um em relação ao outro no que tange ao seu exercício, cuja capacidade, contudo, baseada em padrões formais e ideais de conduta e comportamento, permanece relegada às fronteiras da liberdade "negativa", ao tipo participativo o que se impõe não é senão a necessidade que implica um processo (educacional) que envolve uma espontânea e ativa participação grupal ou comunitária de indivíduos autônomos. Nesse sentido, a base motivacional que se lhes determina, guardando correspondência com uma identificação que dispensa qualquer espécie de influência externa e demanda um envolvimento pessoal, emerge como endógena, transcendendo o âmbito de uma organização ou instituição particular, que encerra um conceito e uma dinâmica que tendem a uma lógica funcional, mecanicista, destituída de indícios de humanidade.

Carregando o sistema cooperativista a pressuposição que envolve, sob a acepção de fundamento, a "economia moral" dos trabalhadores associados, que se contrapõe à ideologia e à prática do laissez-faire, a autossuficiência para a qual tende se lhe encerra como uma "colônia" de interesses unidos no âmbito de cuja 
sociedade o excedente comercial, o "dividendo", é redistribuído entre os seus membros (segundo o valor de suas aquisições, no caso), perfazendo a autogestão a única possibilidade de realização da emancipação econômica do trabalho ${ }^{29}$. Tal condição emerge à medida que viabiliza a participação dos produtores na constituição do governo e no exercício do poder $^{30}$, convergindo para a superação da condição de escravidão social se lhe imposta pelo sistema que implica a existência das classes e, consequentemente, uma relação de dominação que não acena senão com a alienação, que guarda raízes em um processo que traz como base a democracia representativa e dialoga com as fronteiras do liberalismo ${ }^{31}$.

29 Nessa perspectiva, o controle democrático (social) emerge como a diferença essencial entre as formas de propriedade capitalista e cooperativa, cujo sistema encerra a noção de associações de indivíduos que trabalham unidos para a produção e distribuição de bens e outorga, contrapondo-se ao funcionamento da empresa acionária, direitos de voto igualitários para todos os seus membros, independentemente do número de quotas que cada qual tenha no âmbito de uma estrutura que estabelece uma relação entre participação e poder, destituindo o exercício deste último do sentido que implica a posse individual do trabalho abstrato e fossilizado de terceiros.

30 Tendo em vista que "a tendência democrática, intrinsecamente, não pode significar apenas que um operário manual se torne qualificado, mas que cada 'cidadão' possa tornar-se 'governante' e que a sociedade o ponha, ainda que 'abstratamente', nas condições gerais de poder fazê-lo: a democracia política tende a fazer coincidir governantes e governados (no sentido de governo com o consentimento dos governados), assegurando a cada governado o aprendizado gratuito das capacidades e da preparação técnica geral necessárias a essa finalidade.” (GRAMSCI, 2001, p. 50)

31 "O fio que orienta as definições devia caber nos requisitos de um sistema que funciona com base na 'igualdade' - reduzida ao direito de vender (por meio de um 'contrato livre') a sua 'propriedade, em que podemos incluir qualquer arte, ofício ou ciência'. Assim como Rousseau, Kant estava convencido de que na ordem econômica justa 'todos teriam alguma coisa e ninguém teria demais', e por isso aprovava a venda ou a divisão por herança das grandes propriedades. Como essa 'alguma coisa' à venda pela esmagadora maioria das pessoas era apenas sua força de trabalho, que se contrapunha ao poder de exploração e repressão obtido da imensa riqueza possuída pelos poucos, esta contradição teria de ser enfrentada de alguma forma. Ela foi 'esclarecida' por Kant e suas almas gêmeas ideológicas por meio da separação radical da 'forma da lei' de sua 'matéria', de modo que, em nome da racionalidade apriorística, possa sustentar que 'a igualdade geral dos homens' de jure (ou seja: como questão de direito e justiça indiscutíveis) pode 'muito bem coexistir ao lado da maior desigualdade nos graus das posses dos homens'” (MÉSZÁROS, 2011, pp. 275-276, grifos do autor) 


\section{Referências bibliográficas}

BAKUNIN, Mikhail Aleksandrovitch. O socialismo libertário. Trad. de Olinto Beckerman. Col. Bases 22/Teoria. São Paulo: Global Editora e Distribuidora Ltda., 1979;

BRICIANER, Serge (Org.). Anton Pannekoek y los Consejos Obreros. Buenos Aires: Schapire, 1975;

CASSIRER, Ernst. A questão Jean-Jacques Rousseau. Trad. de Erlon José Paschoal e Jézio Gutierre. São Paulo: UNESP, 1999;

GRAMSCI, Antonio. Cadernos do cárcere. Vol. 2. Trad. de Carlos Nelson Coutinho. 2. ed. Rio de Janeiro: Civilização Brasileira;

GRAMSCI, Antonio. Escritos políticos. Vol. 1. Trad. de Manuel Simões. Col. Universidade Livre. Lisboa: Seara Nova, 1976;

GUILLERM, Alain; BOURDET, Yvon. Autogestão: uma mudança radical. Trad. de Hélio Pólvora. Rio de Janeiro: Zahar, 1976;

MACPHERSON, Crawford Brough. A teoria política do individualismo possessivo: de Hobbes a Locke. Trad. de Nelson Dantas. Rio de Janeiro: Paz e Terra, 1979;

MANDEL, Ernest. Da Comuna a Maio de 1968. Lisboa: Antídoto, 1979;

MARCUSE, Herbert. O fim da utopia. Trad. de Carlos Nelson Coutinho. Série Rumos da Cultura Moderna. Volume 31. Rio de Janeiro: Paz e Terra, 1969;

MARX, Karl. A guerra civil na França. Trad. de Rubens Enderle. Col. Marx-Engels. São Paulo: Boitempo, 2011;

MARX, Karl. Crítica da filosofia do direito. Tradução de Rubens Enderle e Leonardo de Deus. 2. ed. (revista). São Paulo: Boitempo, 2010;

MARX, Karl. Formações econômicas pré-capitalistas. Trad. de João Maia. 4. ed. São Paulo: Paz e Terra, 1985; 
MÉSZÁROS, István. Para além do capital: rumo a uma teoria da transição. Trad. de Paulo Cezar Castanheira e Sérgio Lessa. 1. ed. rev. São Paulo: Boitempo, 2011;

MOTTA, Fernando C. Prestes. Burocracia e autogestão: a proposta de Proudhon. São Paulo: Brasiliense, 1981;

POULANTZAS, Nicos. O Estado, o poder, o socialismo. Trad. de Rita de Lima. Rio de Janeiro: Graal, 1980;

PROUDHON, Pierre Joseph. O que é a propriedade? Trad. de Marília Caeiro. 2 ed. Lisboa: Editorial Estampa, 1975;

PROUDHON, Pierre Joseph. Sistema das contradições econômicas ou filosofia da miséria. Tomo I. Trad. de J. C. Morel. Col. Fundamentos de Filosofia. São Paulo: Ícone, 2003;

ROUSSEAU, Jean-Jacques. Do contrato social. Trad. de Lourdes Santos Machado. Vol. I. São Paulo: Nova Cultural, 1999. 